This is the accepted version of the following article: David Lincove, "Data for Peace: The League of Nations and Disarmament 1920-40." Peace and Change , 43, 4(2018): 498-529 which has been published in final form at [https://onlinelibrary.wiley.com/doi/10.1111/pech.12316]. This article may be used for non-commercial purposes in accordance with the Wiley Self-Archiving Policy [ https://authorservices.wiley.com/authorresources/Journal-Authors/licensing-open-access/open-access/self-archiving.html ].

\title{
DATA FOR PeACE: The LeAgue of NATIONS AND DisARMAMENT 1920-1940
}

\author{
by David Lincove
}

\begin{abstract}
Based on Article 8 of the League of Nations Covenant, the League pursued a program to reduce and regulate national armaments to promote peace and security among nations. An integral part of the program was compiling and disseminating data on national armaments holdings, arms trade, and natural resources used to make war. The League anticipated that publishing and sharing arms data would contribute to an environment of greater transparency, international trust, and cooperation. There was a genuine belief among many disarmament supporters that data could be used as a tool to influence public opinion and national leaders, and contribute to the Leagues' negotiations for a disarmament agreement. This philosophy of armaments data led to the publication and use of Armaments Year-Book and Statistical Year-Book of the Trade in Arms, Ammunition, and Implements of War, representing an approach to disarmament that set a precedent for the United Nations.
\end{abstract}

Introduction

In 1924 the League of Nations published the first editions of two annual data sources in support of its efforts to reduce national armaments and control the trade in arms in the years following World War I. Armaments Year-Book offered a compilation of textual and tabular data on military organizations, armaments, and economics organized by countries of the world. Statistical Information on the Trade in Arms, Ammunition, and Material of War ${ }^{l}$ collected and published in tabular format the number and value of arms imported and exported by each nation. 


\section{Data for Peace: The League of Nations and Disarmament 1920-1940}

Authorized by the League Council and General Assembly and compiled by the statistical experts in the Disarmament Section, these publications provided political and military leaders and the general public comparative tools to expose recent and long-term trends in stockpiling and trading armaments by individual nations. The purpose of the data was to identify and question the purpose of an arms buildup and signal potential military threats, but a trend was only a limited predictor of future violence or peace between nations. Leaders needed to discover the intentions behind a buildup of arms in combination with other factors, such as the type of weapons added to the stockpile, historical relationships between nations, and recent public statements from potential belligerents. By making public the status of armaments in each country, the yearbooks served the League's goals of transparency, trust, greater international understanding, and encouraging the power of public opinion for the promotion of peaceful solutions among nations in a difficult postwar environment marked by continuing military conflict and political and economic recovery. In addition, the League intended the data to help establish starting points for disarmament negotiations and the regulation of the arms trade that would result in agreements. The potential agreements would serve as experimental, statistical models for the maintenance of an international balance of military power consistent with national defense requirements in each country.

While recognizing that the League failed in its attempt to reach a disarmament agreement and prevent military aggression, this study argues that the data yearbooks served as vital resources for negotiations and public awareness as called for in Article 8 of the League of Nations Covenant. In addition, the publications set a precedent for arms data compilation and dissemination to improve expert analysis and decision-making about limiting conventional weapons after World War II, when nuclear weapons further complicated the picture. Historical 


\section{Data for Peace: The League of Nations and Disarmament}

studies about the League's disarmament programs investigate diplomacy, national politics, conferences, and efforts to negotiate a broad disarmament agreement. ${ }^{2}$ When formal data publications are mentioned, they are discussed briefly or cited as sources of information. This study contributes to the recent trend toward more nuanced interpretations that account for the League of Nations' constructive contributions to international governance in the 1920s and 1930s by shifting the focus of research from diplomacy to the League's robust collection and use of data. ${ }^{3}$ It demonstrates the League's full acceptance of international trends in formal data compilation and dissemination in its disarmament program, and throughout the organization, to promote community, mutual understanding, problem solving, and greater security and stability among nations.

The Armaments Year-Book and Statistical Information are, like the League of Nations itself, clearly artifacts of the Progressive movement. The faith in the value of statistical data grew out of European and American Progressive belief in the value of the state to solve problems and the broader movement towards "systematic international statistical reporting" that began in the nineteenth century and expanded during and after the war. ${ }^{4}$ League members, deeply influenced by the idea that intergovernmental organization and technical information could solve problems across borders, organized the International Statistical Commission (ISC) in June 1920. The move reflected the League's confidence in statistical experts. The ISC's charge was to coordinate uniform methods and classification of international statistics, centralize statistical information, and ensure the continued cooperation of international organizations. The commission also emphasized the professionalization of statistical work and the importance of seeking opinions of statisticians. 


\section{Data for Peace: The League of Nations and Disarmament 1920-1940}

The League further developed its involvement with statistical methods and compilation in future conferences and publications focused on international economics, finance, labor, and industrial production. The ISC left the work on disarmament data to the League's Disarmament Section, which created its own statistical staff and corps of statistical experts. In general, the greater emphasis on statistical compilation and dissemination, whether from government or intergovernmental organizations, was grounded with a social purpose. ${ }^{5}$ More centralized states meant a greater role for statisticians in "forecasting, monitoring and remedying social and economic ills." In an article about the importance of statistics to the League published in 1921, Lucien March, director of France's Statistique Générale and a member of the ISC, emphasized that "a precise knowledge of the economical and social condition of peoples, their strength and productive power, would be the best guaranty for universal peace." March believed that publicly available, international statistical information would generate greater understanding among citizens of different nations and create an atmosphere of mutual confidence and trust. ${ }^{7}$ March's view was not new. Similar ideas about the contribution of data to society were common in the nineteenth century, and despite the disaster of World War I, statisticians sought to promote the same ideas in efforts for peace. ${ }^{8}$

Although the war weakened domestic Progressive movements for social and political reforms, support for a global organization for peace among nations grew with the help of prominent leaders. President Woodrow Wilson and French political leader Léon Bourgeois represented the continuation of the liberal reform spirit for internationalism. Wilson and Bourgeois could claim only limited success. Wilson, recipient of the Nobel Peace Prize in 1919 as the main architect of the League of Nations, suffered political defeat when the US Senate rejected the Treaty of Versailles and membership in the League. The president's critics, mainly 


\section{Data for Peace: The League of Nations and Disarmament}

Republicans who were not allowed to participate in treaty negotiations, opposed his compromises at the peace conference and any form of binding entanglements in international affairs. In 1920 Bourgeois, a leader in the Radical-Socialist Party and a member of Parliament, became the first president of the League's Council and also received the Nobel Peace Prize as the spiritual "father of the League." 9 Despite the honor both the proponents of a punitive peace treaty and believers of an unrealistic "mystical promise of peace" resisted his philosophy of international solidarity, the arbitration of disputes, and an international military force. Wilson was more influential than Bourgeois in framing the League, but both supported the concept of disarmament even though there would be no international army to enforce agreements.

Dedicated support came from some conservatives as well, such as Lord Robert Cecil in Britain, described as the "foremost internationalist of his generation." On the issue of disarmament and dedication to the League of Nations Cecil's Conservative Party colleagues viewed him as a maverick because of his attempt at independent policymaking in disarmament negotiations and his leadership within the League of Nations Union in Britain. ${ }^{10}$

President Wilson's Fourteen Points for ending the war and rebuilding the postwar world served as a basis for the League Covenant, incorporated into the Treaty of Versailles in 1919. Wilson emphasized the importance of mutual understanding, cooperation, and openness to control armaments and reduce the chances of a future war. In Point Four he called for "adequate guarantees given and taken that national armaments will be reduced to the lowest point consistent with domestic safety." 11 This idea appeared in Article 8 of the League Covenant that became part of the Treaty of Versailles, establishing that "Members of the League recognise that the maintenance of peace requires the reduction of national armaments to the lowest point consistent with national safety and the enforcement by common action of international 


\section{Data for Peace: The League of Nations and Disarmament 1920-1940}

obligations." Alongside mandates to formulate a plan for arms reduction and prevent unregulated arms trade was that "Members of the League undertake to interchange full and frank information as to the scale of their armaments, their military, naval and air programmes and the condition of such of their industries as are adaptable to war-like purposes." 12

The mandate to exchange armaments data among members of the League of Nations was the operationalization of "moral disarmament," one of the pillars supporting the League's concept of open diplomacy and the maintenance of peace, and a hedge against resurgent postwar nationalism. ${ }^{13}$ Moral disarmament, defined as an atmosphere of mutual trust, confidence, understanding, and security among nations, was considered essential before the actual reduction of arms and the alleviation of social and economic postwar problems could be accomplished. ${ }^{14}$ A British secretary at the signing of the Lacarno agreements in October 1925 quoted Belgian socialist Foreign Minister Emile Verdervelde who offered a hopeful vision of the future: "tomorrow I am convinced that it will be relaxation, confidence and moral disarmament — the necessary and sufficient conditions of material disarmament." 15 The League hoped that the exchange and dissemination of armaments information would achieve the reduction in postwar tensions and conflict it envisioned in drafting Article 8, but it recognized that distributing League documents and news releases about disarmament might help generate support from the citizenry and the press in each country. Newspapers were a vital resource that a 1925 League resolution refers to as "the most effective means of guiding public opinion towards that moral disarmament."16

Idealistic efforts to reduce international tensions and promote an environment for disarmament were complicated from the beginning of the League in 1920. Progress on disarmament suffered from the absence of Germany, Russia, and the United States. More 


\section{Data for Peace: The League of Nations and Disarmament}

important was the conflict between the idealism of an intergovernmental project to reduce arms and eliminate wars and the realism of national sovereignty and security. Even as the League sought agreements on disarmament and regulating the arms trade, few nations, particularly the great powers, would relinquish control over their national security policies. This attitude underlined the growing distrust and uncertainty about postwar national security, economic and social distress, and continued wars in Eastern Europe, Turkey, Greece, and Armenia. The League attempted unsuccessfully to enhance international security through multinational agreements to avoid war and improve the chances of disarmament and arms trade regulation in the future. ${ }^{17}$ Furthermore, the League lacked the military power to stop aggression, and national leaders held differing conceptions of national security and national interests.

The League of Nations sought a formula for general disarmament by establishing administrative agencies within the Disarmament Section. It created the Permanent Advisory Commission on Military, Naval, and Air Questions (PAC) in May 1920 composed of military experts from nations on the Council. Among the various responsibilities of the PAC were the control of the arms trade and investigating approaches to reducing national armaments as mandated by Articles 8 and 23 of the Covenant. The PAC drew criticism for its inability to make progress and project a sense of urgency to make disarmament a reality as expected by the public. ${ }^{18}$ This led to the creation of the Temporary Mixed Commission on Armaments (TMC) by the League Assembly in December 1920 but it did not meet until July 16-18, 1921. The TMC consisted of independent civilian representatives chosen by the League Council for their experience in political, social, economic affairs; military representatives from the PAC; and

experts from economic, financial, and labor committees of the League. ${ }^{19}$ The League charged the TMC to investigate and make proposals to the Council consistent with Article 8 of the 


\section{Data for Peace: The League of Nations and Disarmament 1920-1940}

Covenant. This meant creating an international exchange of data on national armaments and drafting agreements to reduce armaments and the international trade in arms by private manufactures and dealers.

The TMC became an object of criticism from its beginning. The Council intended the PAC and the TMC to cooperate to achieve progress on disarmament and the arms trade, but points of conflict arose over status and responsibilities. Conflict originated from the TMC's charge to bring in experts to analyze and propose solutions and to organize a center for gathering data on armaments. In a report of February 25, 1921 French Councilman Léon Bourgeois reported that the PAC already had the authority to use additional experts. He emphasized that "the Commission is not hindered in its work by any lack of expert knowledge, but rather by the Governments and the conditions laid down by them with regard to any understanding relating to a definite reduction of armaments." 20 Additional conflict ensued over the presence of PAC members on the TMC and the method of exchanging data on armaments. The PAC concluded that a new organization to coordinate international exchanges mandated by Article 8 of the Covenant was "superfluous and futile" for nations that signed the Covenant agreement. Rather than systematically gather data on all member nations, a more valuable approach would be to gather data in geographic danger zones where nations were in conflict, and the PAC could organize the exchanges between the great powers. ${ }^{21}$ The Council rejected this alternate approach.

Broader criticism of the TMC came from military and government leaders who viewed the private citizens on the commission as incompetent, potentially too idealistic, and not officially representing their governments' positions. Both the French and British governments were wary of the freedom given private citizens to affect League policy proposals through the 


\section{Data for Peace: The League of Nations and Disarmament}

TMC, and the French sought to hinder its progress. In Andrew Webster's analysis of the TMC he concluded that its "independent representatives must thus be seen as, at best, semi-state actors trying to serve two masters, both the League disarmament vision and their own national interests." 22 Despite the structural criticism of the TMC the League Assembly insisted on a group independent of their government and military establishments and able to offer creative ideas and solutions. Eventually criticism from the PAC and lack of government political support led to its reorganization with a new purpose in 1924 as the Co-ordination Commission with no power to propose policy. ${ }^{23}$

The Council's optimism placed in the makeup of the TMC can be explained not only by its bold approach in the involvement of persons from different nations who were not bound by political and military establishments, but also the League's emphasis on making use of independent experts in statistics, economics, banking, labor, and government. The focus on experts developed from the prewar period of Progressive reform, the reliance during the war on economic and technical information, and the rise of professional and philanthropic elite associations. In the League a "commitment to impartial inquiry had developed, unencumbered by national electoral politics." There was a belief that experts could produce a "truly democratic

and scientifically sound international order." ${ }^{24}$ Reliance on experts indicated the complex nature of disarmament that involved cooperation among different parts of society both internationally and within nations. For most of its three years of existence the TMC was chaired by Algerianborn attorney and French socialist politician René Viviani. Among other expert representatives were former Italian foreign minister, politician and financier Carlo Schanzer; Italian professional statistician Rodolpho Benini; Belgian economist and banker Albert Janssen; and Romanian attorney and economic “technical delegate" Demetre Jancovici. ${ }^{25}$ 


\section{Data for Peace: The League of Nations and Disarmament 1920-1940}

Although the PAC considered developing a questionnaire in 1920 to compile data on armaments, it was not until 1921, with the appointment of the TMC, that a move to gather information began. The data would provide a basis for understanding the status of peacetime armaments and military expenditures in each nation, and it would help direct efforts toward political and military solutions to reduce arms budgets and purchases. The information would help create a process within the League for negotiating an appropriate balance of armaments and peacefully resolving serious disagreements that might lead to violence among nations. ${ }^{26}$ TMC members appreciated the complex nature of international disarmament and realized that there were serious impediments to meeting the mandate of Article 8 of the Covenant. In September 1921 the TMC reported that "of all the problems confronting the League of Nations none is more difficult than the problem of Disarmament, for armaments depend upon policy, policy upon circumstance, and circumstance varies from country to country, and from year to year." 27 The commission considered a proposal in 1922 by member Viscount Esher (Reginald Brett) of Britain who suggested that disarmament and greater international security could be expedited by the reduction of domestic armies and air forces based on statistical ratios similar to the ratios considered at the Washington naval conference in 1922. General lack of support from the TMC and PAC for a scheme using "co-efficients chosen in an arbitrary manner" led him to withdraw it and he resigned from the TMC in 1923. Despite this rejection, the TMC viewed Esher's ideas as emphasizing the importance of gathering data on current national arms holdings. Alternatively, Robert Cecil, who joined the TMC in Spring 1922, proposed mutual defense agreements to achieve a sense of security as a precondition for the actual reduction of arms. It was Cecil's idea, to lay a foundation of trust as necessary for disarmament to be acceptable, that was taken up by the League. $^{28}$ 


\section{Data for Peace: The League of Nations and Disarmament}

The TMC accepted Carlo Schanzer's idea to gather quantitative and qualitative information on the state of postwar national armaments. It stated that statistics were "the only sound basis on which a criterion for dealing practically with the problem of disarmament can rest...Doubtless, statistics are in themselves inadequate to solve the question of armaments, but

they are necessary in order to achieve the aim which we are pursuing." 29 TMC chairman Viviani added that equality in military manpower and expenditure is not "proof of equality of strength" due to the complexity of geopolitical, economic, and historical differences between nations. ${ }^{30}$ Viviani's comment alludes to the complicated issue of qualitative analysis in disarmament, such as the use of a weapon for offensive or defensive purposes and the type and power of armaments deployed.

Between the summer of 1921 and the fall of 1924 a series of recommendations by the TMC and decisions by the League Council and Assembly led to the development of the League's first general compilation of international armament statistics. ${ }^{31}$ Initially conducted by surveying government and military officials throughout the world, the League wanted to get an idea of what governments believed they required for their national security. It also sought a better understanding of the changes in national armaments since 1913, and the "tendency" or trend in each country toward reducing or increasing military manpower, arms used for war, military expenditures, and strength of the economic sectors that support war. The first compilation was a preliminary study published in September 1922 that focused on defense expenditure data from twenty-one League member nations that completed the survey. The TMC went further with a follow up compilation that covered budget expenditures for defense and an accounting of armed forces and major arms for each national army, navy, and air force as of January 1923. The data 


\section{Data for Peace: The League of Nations and Disarmament 1920-1940}

were based on both a survey of nations and a compilation of expenditures for 1921-1923 published in official sources. $^{32}$

These early statistical compilations of armaments led to the TMC's recommendation to the League Assembly in June 1923 to publish an up-to-date and complete yearbook. ${ }^{33}$ The commission rejected reliance on surveys in favor of more complete and expeditious use of data found in existing official and public documents. Its revised procedures for compiling data also relied on sharing completed drafts of armaments data with military attachés in Paris. Attachés could forward their country's data to appropriate military authorities who might propose supplementary information. In this process the League sought to "preserve the independence of the Secretariat" so that it would not be viewed as a propaganda tool for any government. ${ }^{34}$ As conceived by the Disarmament Section a yearbook of arms data would partially fulfill the League's mandate in Article 8 of the Covenant to encourage the open exchange of information related to armaments held and expenditures from as many countries as possible. An annual data source would also reflect potential military power by compiling national data on "wealth in raw materials and their industrial power" 35 and alert nations to arms buildups by potential enemies on their borders. The TMC reported that "from a moral point of view, however, the effect of such exchanges would be considerable. Article 8 of the Covenant was not drawn up with a view of facilitating the work of [military] general staffs. Its object was to improve the political atmosphere by creating confidence... [and] open dealings, instead of mutual distrust." The philosophy of openness implicit in this exchange of information and symbolized by the planned yearbook "would render it possible to nip in the bud any campaign started by an alarmist Press and based upon the armaments of countries considered as potential enemies."36 


\section{Data for Peace: The League of Nations and Disarmament}

\section{ARMAMENTS YEAR-BOOK}

The chief editor of Armaments Year-Book throughout its publication history was Nokhim Sloutzki, ${ }^{37}$ a native of Ukraine who earned a degree in Law from the University of Geneva in May 1917. Considered a "stateless ex-Russian," he received a Nansen passport in a program begun in 1922. ${ }^{38}$ Beginning in April 1921 Sloutzki worked for a few months with the League of Nations in Geneva on the staff of the Economic and Financial Section. His work on trade and production of raw materials and foodstuffs before and after the war brought him in contact with Italian statisticians Corrado Gini and Felice Vinci. ${ }^{39}$ After a few months with the International Labour Organization in Geneva, he went back to the League in March 1922 as a statistician with the Disarmament Section where he worked from 1922 to 1940 . He remained employed by the League until its final days in April, 1946 and then joined the staff of the United Nations working on armaments issues. Sloutzki wrote that he was "closely involved with both the technical work done by the League and the political efforts, under League auspices, to develop central control systems for the international trade in armaments." ${ }^{\circ 0} \mathrm{He}$ also published books and journal articles about arms limitation and disarmament. ${ }^{41}$

Armaments Year-Book appeared in 1924 in English and French (Annuaire Militaire). The English edition with 844 pages was available as part of the League's documentary series by subscription. Publishing agents such as Britain's Constable and Company LTD and later by George Allen and Unwin LTD distributed the yearbook worldwide in both cloth binding and paperback. ${ }^{42}$ At this time no other reference work like it was available. Before the war, beginning in 1874, a guide to national militaries and arms had appeared in German edited by Colonel Heinrich von Löbell. Under varying titles and editors, Löbell's Jahresberichte über die Veränderungen und Fortschritte im Militärwesen [Löbell's Annual Reports on Changes and Progress 


\section{Data for Peace: The League of Nations and Disarmament 1920-1940}

in the Military] appeared in forty-eight volumes until 1935 with a gap during and after the war when it reappeared in 1926. The guide offered evaluations and statistical data on military capabilities in most countries. ${ }^{43}$ A reviewer praised the work in 1926 for its depth of information, unique critical approach, and impartiality. ${ }^{44}$ Löbell's had an organization similar to the League's yearbook with a combination of extensive text and statistical tables arranged by nation, but the German work also included a topical section.

The editors of Armaments Year-Book explained their methodology for the compilation in each edition, but it was not until the Preface of the final edition, published in early 1940 in the midst of a new war, that they addressed the value of the work. The yearbook was described as "authentic" and published with "complete objectiveness... [and] authority" compared with inaccurate information appearing in the world press. ${ }^{45}$ There was no doubt that countries withheld data but the League hoped that sufficient data would be openly available to illustrate realistic trends over time in the reduction or increase of armament holdings and expenditures. The editors of the 1940 edition offered strong justification of the great effort by the League to provide the information despite its failure to halt a new arms buildup and the onset of a new war that began while they compiled the new edition.

In the 1924 yearbook the editors organized the work in three parts, "Military Forces (Land, Sea and Air)," "Budget Expenditures on National Defense," and "Industries capable of being used for War Purposes." In each section League member nations and nonmembers appeared in alphabetical order. The editors provided descriptive text and statistical data broken down into detailed categories, such as military organization, number of arms of various types, military schools, naval tonnage by ship type, and aircraft. Budget data relating to national defense were presented raw from the original sources without attempting to standardize the 


\section{Data for Peace: The League of Nations and Disarmament}

information using a basis for measurement, such as converting all monetary figures to French francs. The third section printed non-standardized data about the output, imports, and exports of industries providing vital raw materials of military importance, such as coal, petroleum, ores, metals, chemicals, cotton, and rubber. A brief section of disarmament agreements and data sources appeared at the end of each chapter.

The data sources for the information varied greatly depending on the data made public by each country. In the 1924 volume the work covered thirty-seven nations. For Albania no published sources were used and editors relied on data supplied by the government which reported that there were barely enough arms for the 10,691 soldiers and gendarmerie in the country. For the Soviet Union only a few sources were available, such as the newspaper Izvestia, Soviet laws and decrees, and a government publication on the organization of the army. From these documents the yearbook provided, for example, information on the organization and composition of the Red Army and its system of recruitment and training, but no statistics appeared on the number of soldiers in the ranks. Only one statistical table was included listing numbers of naval vessels, such as the country's three battleships and cruisers weighing 70,110 tons. Data for Japan originated from direct communications with the Japanese government and existing statistical publications, such as The Japan Year-Book and Annual Return of the Foreign Trade of the Empire of Japan. Among the large amount of data was a figure showing Japan's expenditures for the Army and Navy had decreased from 649,750,000 Yen in 1920/21 to an estimated 483,782,000 Yen in 1923/24, but the apparent decrease can be interpreted differently depending on price indexes shown for 1913 versus $1920 .^{46}$

The sections of the yearbook for Great Britain and the British colonies were extensive. Among the sources for Britain were parliamentary documents with budget estimates and 


\section{Data for Peace: The League of Nations and Disarmament 1920-1940}

appropriations to the military, Army Estimates of Effective and Non-Effective Services for the Year 1924-1925, and communications with government agencies. Information about the colonies and protectorates excluding India appeared separately, but there was one source list, mainly the Notes on the Land Forces of the British Dominions, Colonies and Protectorates published by the War Office of the British government. The chapter on India, for example, included a large section with detailed statistics on the organization of British and Indian forces, such as a total fighting force of 235,652 soldiers among whom there were 144,617 Indian officers and men in rank. $^{47}$

Data on the United States were plentiful and originated from published national budgets, statutes, military regulations and reports, the Statistical Abstract of the United States, and other published government documents. Among the data are detailed tables showing active army and national guard strength in mid-1923, and a table showing the estimated decrease in defense expenditures from $\$ 598,937,000$ to $\$ 548,531,000$ between $1922 / 23$ and $1924 / 25$ with price indexes shown for 1913 and 1922/23..$^{48}$

During the years that the Armaments Year-Book appeared, the editors sought to expand participating states and update the information. The number of nations represented increased from thirty-seven in 1924 to fifty-seven in the 1925/1926 edition, reaching a high mark of sixtyfour in 1933. That number held steady until the final edition of 1939/1940 contained information for sixty-three states. With the exception of the special edition of 1932 discussed below, the editors sought to maintain consistency in the presentation and organization of the textual and tabular data. Organizational changes over the years included the expansion of the section of relevant agreements, treaties and conventions, maps, graphs, and statistical tables. The widely varied sources, currencies, measurement standards, classification of weapons, amounts of 


\section{Data for Peace: The League of Nations and Disarmament}

information for different countries, and the need to translate from documents in many languages

demonstrated the massive amount of work required to compile and organize the yearbook. ${ }^{49}$ The data could be difficult to interpret, but from the perspective of contemporary and future researchers, the yearbook served as a guide to historical data resources published by each country.

Government and public interest in Armaments Year-Book was evident from its use by public officials and the press. An indirect reference to the yearbook appeared in August 1926 in a letter from Walter Roberts, a British representative at League discussion of the Preparatory Commission, to Foreign Minister Austen Chamberlain. Roberts mentioned that documents prepared by both Italian and French delegations agreed that the yearbook would serve as a useful resource for control of armaments. The Italian document stated that it was "the only practicable or desirable method of control" compared with investigative commissions of enquiry. ${ }^{50}$ The yearbook was clearly cited for statistical data in other British foreign policy documents during the period of the world disarmament conference in 1933 and 1934 related to negotiations on the level of naval armaments ${ }^{51}$ and German parity with other European armies and air forces. ${ }^{52}$ British cabinet proceedings also reveal use of data from the yearbook to demonstrate the military needs of the Committee of Imperial Defence in an environment of decreasing British arms expenditures while there were increases among the other great powers between 1925 and 1933 . Reliance on the yearbook was also clear when the Foreign Office cited data on air forces of several nations and compared it to what seemed to be exaggerated figures reported by Hitler's regime in the spring of $1935 .^{53}$

References to data in the yearbook appeared in the debates of the British House of Commons and the US Congress. On November 11, 1936 Britain's Under Secretary of State for 


\section{Data for Peace: The League of Nations and Disarmament 1920-1940}

Air Sir Philip Sassoon responded to a request for the "ratio of aeroplane and seaplane strength of Great Britain as compared with that of France, Germany, and Italy.” Sassoon referred the representative to the recently published Armaments Year-Book. Three years later in early May, 1939 Prime Minister Neville Chamberlain was asked to produce a white paper comparing compulsory conscription data from European nations. Chamberlain, citing Armaments YearBook, said, "in these circumstances I do not think that the labour involved in the preparation of a White Paper would be justified." ${ }^{54}$ Similar use of the yearbook occurred in Congress. In June 1932 Mississippi Democratic Representative Ross Collins introduced tables from several editions of the yearbook to demonstrate that the House should not provide excessive funding to the War Department given comparative data from other nations. ${ }^{55}$

The number of references to the yearbook in British cabinet and foreign policy documents, the House of Commons, and in the US Congress was modest, although use may have been higher than is obvious from citations because there were instances when statistics were quoted with no clear source. This use of the yearbook offers an indication that government officials relied on it as an important source of information to assist with disarmament policymaking. The usefulness of the yearbook to national decision makers cannot, however, be accurately measured with references. Instead, we can understand the importance of the data source from the broader disarmament discussion and popular interest in the publication, both of which clarify the central place of numerical comparisons in armaments negotiations. The data was very important to detect national arms buildups over time, but no matter what the data revealed, its completeness could be questioned, and it would never overrule national sovereignty for purposes of security. 


\section{Data for Peace: The League of Nations and Disarmament}

Popular references to the yearbook appeared in newspapers and magazines offering reviews, letters, and news. Most of the reviews were positive, praising it as a useful reference source that clarified the great sums of money spent and the types of armaments that nations considered necessary to maintain their defenses in the postwar environment. ${ }^{56}$ American lawyer and internationalist Raymond Fosdick referred to the yearbook's "scientific approach to the problem of disarmament. It is essential spade work in laying the foundations of peace."57 Authors cited the yearbook in a variety of scholarly and popular periodicals in political science and international affairs from the 1920 s to the 2000 s in source lists or when reference was made to the level of armaments held by a nation. ${ }^{58}$ In a review of the 1925-1926 edition Philip Noel Baker, a British Labour Party member, disarmament expert, and Professor of International Relations at the University of London, declared it "the most complete manual of its kind that there has ever been." It is "worth the expense and trouble...for it helps us more clearly to realize what are the armaments which we discuss so vaguely, though so much."59 In August 1928 the New York Times gave an entire page with maps, charts, and a graph illustrating the tremendous cost of arms as revealed in the most recent yearbook and the writer wondered whether the public would accept their leaders' explanation that disarmament is insoluble. ${ }^{60}$ When the 1937 volume appeared, the editor of The Times of London noted that even though it was impossible to secure accurate data on German and Italian arms, "the volume, like its predecessors, is indispensable to those who require to have the data available as to the armies, navies, and air-forces of the world." 61

Whether the yearbook was used by the media or by government, it "became," according to historian Andrew Webster, "an essential and well-respected source," 62 that served the League 


\section{Data for Peace: The League of Nations and Disarmament 1920-1940}

of Nations' purpose to publicize international arms information and attempt to reduce the impact of rumor and propaganda.

Critics emphasized the limitations of the information in Armaments Year-Book, particularly that data for two or more nations were difficult to compare due to differences in definitions of terms (e.g. battleship), standards of measurement (e.g. petroleum), and their qualitative value of offensive or defensive weapons. Just as important, the publication could not include data withheld as secret by countries and it could be out of date by the time it was published. In a review of the 1930 edition Lt. Col. Georges-Eugène Lestien, professor at l'École Supérieure de Guerre, pointed out the lack of information on German armaments compared with smaller nations. ${ }^{63}$ Noting the lack of published data, Denys Myers, research director of the World Peace Foundation, believed that "this condition of calculated misrepresentation [by national leaders] was so deeply impressed upon the whole area of the problem that... there has been a constant emphasis upon bringing to light what states are doing, allegedly in the name of national defense." ${ }^{64}$ In 1935 William T. Stone, vice-president of the Foreign Policy Association and armaments expert, believed that the yearbook was useful but criticized it for data that was "sketchy and inadequate or sadly out of date." It lacked information on "the huge stocks of war material, such as guns, tanks and ammunition built up by the great powers during the past decade. It is impossible, from the scanty figures in the Year-Book, to estimate the actual strength of the air forces of the principal powers, or the reserve strength of the armed forces of those countries which maintain the conscript system." 65

The most dramatic changes to the yearbook appeared temporarily in the 1932 edition in preparation for the World Disarmament Conference and emphasized the importance of data in the negotiations. Disarmament documentation related to work of the Preparatory Commission 


\section{Data for Peace: The League of Nations and Disarmament}

for the Disarmament Conference (1926 to 1932) and in the proceedings of the conference (19321934) often contained discussions on defining which armaments to measure and comparing statistical data based on conditions in each country. There was no consensus on the status and trends in the numbers of soldiers in various ranks, the number of tanks and military aircraft, sizes of airplane engines, tonnage and nation-to-nation ratios of naval destroyers and cruisers, military expenditures, and arms manufacturing. ${ }^{66}$ Britain's delegate, Arthur Henderson, who was president of the conference, announced at its opening session on February 2, 1932 that an agreement on these details would save governments billions of dollars in arms expenditures. ${ }^{67}$ For the convenience of the conference delegates, the special edition of Armaments Year-Book contained more concise information than past editions on each country's armaments, military expenditures, and the organization and composition of military forces. Delegates received a copy and it was available for purchase by the public. ${ }^{68}$ Much of the data came from a special survey that requested data according to a consistent measurement standard for specific values, such as monetary value of military expenditures or tonnage of destroyers. For example, in 1931 Italy held seventy-five submarines with a total "standard displacement" tonnage of 53,664 compared with 110 submarines with a tonnage of 97,875 held by France. With the use of more standardized measures the League sought a valid basis for comparing data, but the editors admitted that it was "impossible" to compare certain data over time, such as "effectives" [ie. data on military manpower] shown in the survey with data derived from budgetary information appearing in previous yearbooks. ${ }^{69}$ Forty-eight governments, including the United States, reported data. ${ }^{70}$

Denys Myers, research director of the World Peace Foundation, described the new compilation effort as "the first time in history official records of armed strengths on a 


\section{Data for Peace: The League of Nations and Disarmament 1920-1940}

comparable basis" was attempted. The new data compilation from a survey resulted in substantial differences with previous editions of the yearbook based on published sources. Yet Myers admitted that even the new survey data could be difficult to compare due to technical differences among nations in reporting information. Despite the problems Myers conceded that the new data system was a great improvement, and he expected Armaments Year-Book to use the new compilation model in future issues. ${ }^{71}$ Although the same survey data related to military personnel also appeared in the 1933 and 1934 editions of the yearbook along with information from publications, it would not be repeated afterwards.

The TMC's other annual data compilation edited by Nokhim Sloutzki, Statistical Information on the Trade in Arms, began publication in September, 1924 in English and French (Renseignements Statistiques sur le Commerce des Armes, Munitions, et Matériel de Guerre). As with its counterpart, the yearbook followed the mandate for the international exchange of information and it reinforced a program of publicity and transparency, but it was initiated in response to the failure of the arms trade Convention of St. Germain in 1919. The League Assembly asked the TMC to prepare a new proposal limiting the arms trade and to compile data on the value, quantity, and destination of arms and munitions exported and imported. Editors derived the data from trade statistics published by each country pertaining to infantry weapons and explosives leaving out large items such as warships and artillery. The 1924 edition provided data for twenty-three nations, and this number grew to fifty-nine nations plus colonies,

protectorates, and mandated territories in the final edition in September, $1938 .{ }^{72}$ For example, the 1926 edition showed that between 1920 and 1924 Bulgaria, allied with the Central Powers in the past war, was mainly an importer of explosive munitions and that the value of those imports increased from 1,422,900 Levas to 9,652,900 Levas. The amount of explosive munitions 


\section{Data for Peace: The League of Nations and Disarmament}

purchased increased from 15.76 metric tons to 84.84 metric tons. By 1924 Germany and France were the sources of $75 \%$ of Bulgaria's imports of this material. The last edition of the yearbook revealed that Bulgaria's purchases of munitions were very large in 1935 (e.g. 602.19 metric tons for rifle and revolver cartridges alone) compared with other years from 1933 to 1937, and their main arms supplier continued to be Germany with Italy, Hungary, and Czechoslovakia surpassing France. ${ }^{73}$ This data was derived from Statistique du Commerce Extérieur (Sofia).

Sloutzki explained that the information in Statistical Year-Book of the Trade in Arms was "designed to serve as a working instrument for various bodies of the League in charge of preparing a convention on arms traffic control." He recognized there were serious flaws in the data due to differing ways nations compiled their data and the dynamics of arms trade. There was no uniformity in the nomenclature of arms trade statistics, and reporting of data was inconsistent and unreliable. Trade statistics did not show local manufacture of arms that remained in the country of origin. Despite the flaws in the yearbook, Sloutzki believed that recognizing the expansion or reduction of arms exports and imports over the course of several years was more important than whether the statistics were completely accurate. ${ }^{74}$ Trends in the national import of armaments might raise questions about the military and political motivations of a country's leaders, particularly if an arms buildup was occurring.

American journalist John Gunther offered one of the few reviews of the arms trade yearbook. Gunther wrote a mixed review of the 1935 yearbook he described as "woefully inadequate. It gives only the figures that various governments wish to be published; it's always out of date; it does not include really expensive items like battleships and airplanes; and it takes no account of smuggling....However, it is the best thing we have and, despite its deficiencies, it contains some pearls of information." ${ }^{.75}$ The fact that it had some usefulness was why it was 


\section{Data for Peace: The League of Nations and Disarmament 1920-1940}

cited twice in the British House of Commons debates on British arms sales to South America during the Chaco War and at least once in a Foreign Office communication regarding Chinese disregard for British arms dealers. ${ }^{76}$

Sloutzki believed that Armaments Year-Book and Statistical Year-Book of the Trade in Arms were complimentary by presenting a broad approach to publicizing the state of armaments in each country and providing an information system that would contribute to a full evaluation of the quantity, quality, and purpose of armaments. He noted that the public showed little engagement with disarmament discussions because it was too complex. The arms trade yearbook "shared the fate of most of the League of Nations' Secretariat publications. These were of interest exclusively to governments, certain public libraries, a few specialized journals, and the individuals who kept abreast of the proceedings of the League of Nations." If there was any chance that the public could have influenced their governments to bring a halt to increasing armaments, the arms trade yearbook would have needed a complete overhaul and the publication of a special edition with less focus on statistical data for the public. ${ }^{77}$ In a 1941 publication, Sloutzki wrote that after general and complete disarmament there would be no need for either yearbook. More realistically and with possible bitterness about unsuccessful efforts for disarmament, he noted, "their aim was to show how, in peace time, the world prepared for war; once the war had broken out, the Year-Books had no further reason to exist."78

By 1934, the failure of the World Disarmament Conference was a foregone conclusion given the irreconcilable disagreements and Hitler's decision in October 1933 to withdraw Germany from the conference and the League. The lack of agreement prior to Hitler coming to power was due to the complicated details of the negotiations. Disarmament negotiations required nations to decide the number and quality of weapons necessary for each country, but 


\section{Data for Peace: The League of Nations and Disarmament}

reaching an agreement was fraught with difficulty. Specific problems involved defining terminology, the size of national military forces, military training, geography, communication networks, boundaries, fortifications, and national image. ${ }^{79}$ The reality was "their need to equate different types and numbers of weapons and, then, meet their unique military requirements concerning both international security and national sovereignty." 80 Germany had been secretly rearming for years and unsuccessfully pushing for arms parity with other great powers. After taking power, Hitler rebuked unfair disarmament negotiations and publicly announced his intention to rearm Germany in violation of previous treaty agreements. Zara Steiner refers to the "myth of disarmament" in an environment of rearmament, and she points to this public failure of the League as "its singular discredit." ${ }^{11}$ Sloutzki recalled that by 1935 the Disarmament Section "virtually ceased its activities."

Despite the reduction of the League's disarmament activities, Armaments Year-Book persisted every year until its final issue in early 1940 after a new war had already started in Europe. Statistical Year-Book of the Trade in Arms also continued until its last issue in 1938. Both publications illustrated the dangerous build up of armaments in the few years prior to the onset of war in September 1939. In 1935 William T. Stone noted in his review of the new edition of Armaments Year-Book that it revealed increased arms expenditures by $\$ 40$ billion during the past ten years, with increases ranging from 25 percent for France to 388 percent for Japan, despite the League's Covenant and years of effort for disarmament. ${ }^{83}$ The 1939/1940 Armaments Year-Book revealed that the total expenditures for national defense in Italy increased from 5,247 million Lire in 1934/1935 to an estimated 13,593.8 million Lire in 1938/1939. Based on price inflation factored $(1929-30=100)$, expenditures increased 31.6 percent ( 76 to 100$)$ in four years. ${ }^{84}$ 


\section{Data for Peace: The League of Nations and Disarmament 1920-1940}

The continued publication of armaments data supplied evidence of the world's buildup of arms, but the data may also have been viewed with a glimmer of hope and encouraged the League to persist. Although the world seemed to be on a path to a new war, Sloutzki believed that the continuation of the Statistical Year-Book of the Trade in Arms provided broad knowledge of arms trafficking that might influence public opinion and encourage nations to pull back from the brink of disaster. The armaments race could be measured best with exports of weapons, military expenditures, and strength of armed forces. ${ }^{85}$ In an explanation for the League's unwillingness give up its disarmament efforts, former Deputy-General of the League of Nations Frank P. Walters wrote, "it was characteristic of the League of Nations that it was never ready to confess to defeat in any important purpose...It must always be ready to try again." 86 Despite the positive spirit, in 1939 the Disarmament Section became part of the Department of General Affairs in a broad cost-cutting move by the League, and the documentation generated on behalf of disarmament diminished substantially.

\section{LEGACIES}

When the United Nations replaced the League of Nations in 1946, the new organization sought to correct the perceived deficiencies of the League's structure and way of operating, but the UN was fundamentally rooted in the League's internationalism. The UN accepted the League's goal of promoting peace and security through multilateralism, transparency in arms holdings and trade, moral and material disarmament, collective security, and a greater sense of community and shared human values. Much of the League's work in international social and economic affairs, its use of experts, and its philosophy of organization and forums for the discussion of ideas and the settlement of international disputes, became part of the UN's program from its conception. 


\section{Data for Peace: The League of Nations and Disarmament}

The UN carried on the idea of the "primacy of expert advice in the new specialist agencies [that] represented the continued power of the idea that the world could be directed by using figures, numbers, and statistical categories." 87

The compilation of data on national armaments was not a priority for the UN, although Article 11 of the UN Charter gave the General Assembly the right to consider principles for reducing and regulating armaments, and Article 26 established that the Security Council would consult with the Military Staff Committee to "establishment of a system for the regulation of armaments." 88 The General Assembly passed resolutions favoring arms control and data collection and dissemination as early as December 1946. ${ }^{89}$ The US proposed in April 1952 that any system of "guaranteed disarmament" must include "progressive disclosure and verification on a continuing basis of all armed force." 90 A return to organizing and publishing international arms data on a large scale was delayed for decades, possibly because of the data published by private organizations, particularly the International Institute of Strategic Studies, the Stockholm International Peace Research Institute (SIPRI), and the US government. ${ }^{91}$ The UN did not act until it published aggregate data on national defense expenditures in the Yearbook of National Account Statistics beginning in 1957.

The UN began publishing detailed, national armaments data in 1981 with Military Expenditures in Standardized Form Reported by States in annual reports to the Secretary General. This was intended as a first step in a concerted effort to persuade nations to reduce their expenditures on arms, much like the League developed its data sources as a psychological foundation for disarmament negotiations. The UN's focus on lowering military expenditures, supported by the Soviet Union, occurred just before the presidential inauguration of Ronald 


\section{Data for Peace: The League of Nations and Disarmament 1920-1940}

Reagan who supported and implemented large increases in the US defense budget. The report is now known as the UN Report on Military Expenditures. ${ }^{92}$

In 1992 the UN Register of Conventional Arms became operational compiling data by country for seven weapon categories, including battle tanks, armed combat vehicles, combat aircraft, attack helicopters, large caliber artillery, warships, and missiles and missile launchers. The data covers exports and imports, local weapons production, and weapons holdings. The UN added small arms to the register in 2003. Associated with the register is The Global Reported Arms Trade. Both contain data reported by UN member states in accordance with the standards and definitions of trade in each nation. The motivation for the Register developed in the aftermath of the first Gulf War, a conflict partially blamed on the huge buildup of armaments in Iraq. Although the UN initially sought greater control over the trade in destabilizing arms, problems related to defining which arms would be regulated and opposition from arms manufactures led only to the implementation of the Register. This minimal approach to the problem of arms proliferation pursued the same approach as the League of Nations with its emphasis on transparency and the danger of the destabilizing accumulation of arms. ${ }^{93}$

Usually positive assessments of the League focus on its efforts in areas other than disarmament, such as international health improvement, labor relations, and eliminating opium smuggling and slavery. Even though the League failed in its efforts to reduce armaments and maintain international peace after World War I, arms data served as a logical and essential information tool in the quest for the reduction of arms as a major contributor to the maintenance of peace. The belief in the value of compiling and disseminating data about world armaments provided a basis for disarmament discussions by offering information to compare national arms positions and find appropriate levels of arms for peacetime defense. Governments and the press 


\section{Data for Peace: The League of Nations and Disarmament}

used the data because they viewed the yearbooks as trusted sources. However, the varied and complicated nature of the information made its value theoretical. National self-interests and sovereignty, international distrust, and rivalries for power were real, compared with theoretical ratios of specific armaments and expenditures.

Nevertheless, the League of Nations' experience with arms data compilation and dissemination established patterns of thinking and organization that emphasized the role of expert, unbiased data collection in international discussions, and decision making on arms limitation and national security. Data served the League's attempts to create an environment conducive to international trust and security through moral disarmament, and the experience influenced future arms control efforts and set a precedent for similar efforts after World War II. The influence is evident in data publication by private organizations, government, and the United Nations. Scholars continue to cite Armaments Year-Book and Statistical Year-Book of the Trade in Arms or sources that rely on them. ${ }^{94}$ This is a legacy of the League, to compile and disseminate national armaments data to promote peace in the interwar years.

\footnotetext{
${ }^{1}$ The League of Nations published both yearbooks as part of the document series League of Nations Publications, IX Disarmament [referenced below as LNP-IX-D] (Geneva: League of Nations, 1920-1940). Armaments Year-Book. (Geneva: League of Nations, 1924-1940). Statistical Information on the Trade in Arms, Ammunition, and Material of War (Geneva: League of Nations, 1924-1925) followed by The Statistical Information on the Trade in Arms and Ammunition, and Materials of War (1926-1928); Statistical Year-Book of the Trade in Arms, Ammunition, and Implements of War (1929-1938).
} 


\section{Data for Peace: The League of Nations and Disarmament 1920-1940}

${ }^{2}$ Selected key scholarship from recent years on interwar disarmament are Zara Steiner's two-volume contribution to interwar history in Lights That Failed: European International History 1919-1933 (Oxford University Press, 2005) and The Triumph of the Dark: European International History 1933-1939 (Oxford University (Press, 2011); Keith Hamilton and Edward Johnson, Arms and Disarmament in Diplomacy (London: Vallentine Mitchell, 2008); Carolyn J. Kitching, Britain and the Problem of International Disarmament 1919-1934 (New York: Routledge, 1999); Arms Limitation and Disarmament: Restraints on War, 1899-1939, Edited by B. J. C. McKercher (Westport: Praeger, 1992); Sally Marks, The Illusion of Peace: International Relations in Europe, 1918-1933, $2^{\text {nd }}$ Edition (New York: Palgrave, 2003); Andrew Webster, "Making Disarmament Work: The Implementation of the International Disarmament Provisions in the League of Nations Covenant, 1919-1925," Diplomacy and Statecraft 16(2005), 551569; and Andrew Webster, "From Versailles to Geneva: The Many Forms of Interwar Disarmament," Journal of Strategic Studies 29(April 2006): 225-246.

${ }^{3}$ Examples of recent studies offering more positive or balanced perspectives are Susan Petersen, The Guardians: League of Nations and he Crisis of Empire (New York; Oxford University Press, 2015), 7-9, 397-399; J. Simon Rofe, "Prewar and Wartime Postwar Planning: Antecedents to the UN Moment in San Francisco, 1945," in Wartime Origins and the Future United Nations, ed. Dan Plesch (Routledge, 2015), 20-31; Susan Pedersen, "Back to the League of Nations," American Historical Review 112 (October 2007): 1091-1117.

${ }^{4}$ Helmut K. Anheier, "Data Systems and Reporting, Global," Encyclopedia of Global Studies (Thousand Oaks, Ca.: Sage, 2012), 357-358. Also see Jean-Guy Prévost and Jean-Pierre Beaud, Statistics, Public Debate and the State, 1800-1945: A Social, Political and Intellectual History of Numbers (London: Pickering and Chatto, 2012), 49-61.

${ }^{5}$ H. R. Coates, "Report of the International Statistical Commission Appointed By the Council of The League of Nations," Quarterly Publication of the American Statistical Association, $3^{\text {rd }}$ Series, no. 133, 17 (March, 1921), 635638; Charles K. Nichols, "The Statistical Work of the League of Nations in Economic, Financial and Related Fields," Journal of the American Statistical Association 37, 219(September, 1942), 338-341; United Nations Statistical Commission: Sixty Years of Leadership and Professionalism in Building the Global Statistical System 1947-3007 (New York: United Nations, 2007), 2;

${ }^{6}$ Prévost and Beaud, Statistics, Public Debate and the State, 1800-1945, 89.

${ }^{7}$ Lucien March, "International Statistics and the League of Nations," Quarterly Publication the American Statistical Association, $3^{\text {rd }}$ Series, no. 133, 17(March, 1921), 629 (quote), 635. 


\section{Data for Peace: The League of Nations and Disarmament}

${ }^{8}$ Prévost and Beaud, Statistics, Public Debate and the State, 1800-1945, 61, 80-83.

${ }^{9}$ James T. Kloppenberg, Uncertain Victory: Social Democracy and Progressivism in Europe and American Thought 1870-1920 (New York: Oxford University Press, 1986), 303-304. See also Colin Dueck, Reluctant Crusaders: Power, Culture and Change in American Grand Strategy (Princeton: Princeton University Press, 2008), 44-81.

${ }^{10}$ Gaynor Johnson, Lord Robert Cecil: Politician and Internationalist (Farnham Surrey: Ashgate, 2013), 274-275, 288; Helen McCarthy, The British People and the League of Nations: Democracy Citizenship and Internationalism 1918-1945 (Manchester: Manchester University Press, 2011), 58-60; Viscount Cecil of Chelwood, All The Way (London: Hodder and Stoughton Ltd., 1949), 174-192.

${ }^{11}$ Woodrow Wilson, “Address of the President of The United States, Delivered at a Joint Session of the Two Houses Of Congress, January 8, 1918," in Papers of Woodrow Wilson, v. 45 (Princeton, NJ: Princeton University Press, 1984), 537.

12 Text of Article 8 in Avalon Project (Yale Law School, 2008), http://avalon.law.yale.edu/20th_century/leagcov.asp (accessed November 30, 2016) See also Article 23 regarding the right of the League to regulate trade in arms. For works on the covenant and meaning of Article 8 see F. S. Northedge, The League of Nations: Its Life and Times (New York: Holmes \& Meier, 1986), 25-45, 54-56; F. P. Walters, History of the League of Nations, vol. 1 (London: Oxford University Press, 1952), 25-39, 218-219; John Spencer Bassett, The League of Nations: A Chapter in World Politics (New York: Longmans, Green and Co., 1928), 1-27; P. J. Noel Baker, Disarmament (London: Hogarth Press, 1926), 26-36, 331.

${ }^{13}$ Glenda Sluga, Internationalism in the Age of Nationalism (Philadelphia: University of Pennsylvania Press, 2013), 45-78.

14 "The Reduction of Armaments, Report of the Third Committee to the Third Assembly of the League of Nations," September 22, 1922 in LNP-IX-D (Geneva: League of Nations, 1922), 13. (A.124.1922.14); League of Nations, Conference for the Reduction and Limitation of Armaments, "Moral Disarmament," February 24, 1932 in $L N P$ - $I X-D$ (Geneva: League of Nations, 1932), 1-11. (Conf. D. 98) See also Denys P. Myers, World Disarmament: Its Problems and Prospects (Boston: World Peace Foundation, 1932), 3-5.

${ }^{15}$ British Secretary's Notes of the Ninth Plenary Meeting of the Locarno Conference held on October 16, 1925, Documents on British Foreign Policy 1919-1939, Series 1 - Volume 27, Appendix - (London: H.M.S.O, 1986), item 


\section{Data for Peace: The League of Nations and Disarmament 1920-1940}

15, p. 1174. See also Mr. Campbell (Paris) to the Marquess of Reading, Reports speech by M. Dumesnil, September 7, 1931, French Minister for Air, Documents on British Foreign Policy 1919-1939, Series 2 - Volume 3 (London: H.M.S.O., 1948), Item 216, p. 486-487.

${ }^{16}$ League of Nations, Official Journal, Special Supplement 29, vol. 32(Geneva: League of Nations, 1925), 32; LNOJ, 3(May, 1922), 407. See also Kaarle Nordenstreng \& Tarja Seppa, "The League of Nations and the Mass Media: The Discovery of a Forgotten Story," XV Conference of the International Association for Mass Communication Research, Section of International Communication session on "Communication and Peace" (New Delhi: CIAMCR, 1986), 5.

${ }^{17}$ Goldblat, Arms Control: The New Guide to Negotiations and Agreements, ${ }^{\text {nd }}$ ed, 23, 24; Andrew Webster, "Making Disarmament Work," 561-564; Kellogg-Briand Pact 1928," in The Avalon Project(Yale Law School, 2008), http://avalon.law.yale.edu/20th_century/kbpact.asp. (accessed June 5, 2015). "Treaty of Mutual Guarantee between Germany, Belgium, France, Great Britain and Italy; October 16, 1925 (The Locarno Pact)" in The Avalon $\operatorname{Project(Yale~Law~School,~2008),~http://avalon.law.yale.edu/20th~century/locarno~001.asp~(accessed~June~5,~2015).~}$ See also Lorna Lloyd, Peace Through Law: Britain and the International Court in the 1920s (Woodbridge, Suffolk: Boydell Press, 1997), 29-31, 37-38, 90-91, 123.

${ }^{18}$ Andrew Webster, "Making Disarmament Work," 553.

${ }^{19}$ LNOJ 2(March-April 1921), 146-148. See also Walters, History of the League of Nations, vol. 1, 217-230; Alden H. Abbott, "The League's Disarmament Activities - and the Washington Conference," Political Science Quarterly 37(1922), 1-24.

${ }^{20}$ LNOJ 2(March-April 1921), 147.

${ }^{21}$ LNOJ 4(August 1923), 1034 (quote) -1036.

${ }^{22}$ Andrew Webster, “Absolutely Irresponsible Amateurs": The Temporary Mixed Commission on Armaments, 1921-1924," Australian Journal of Politics and History 54, 3(2008), 388 (quote), 373-387; LNOJ 4(April 1923):

426; LNOJ 4(August 1923), 1035-1036; Cabinet memorandum CAB 24/164/6, January 1924, The National Archives, The Cabinet Papers 1915-1988 (http://discovery.nationalarchives.gov.uk/details/r/D7725785).

${ }^{23}$ LNOJ 2(December 1921), 1134-1136; LNOJ 5 (October 1924), 1379-1380. See also CAB/24/164/6, C.P. 6 (24), Confidential Foreign Office memorandum to the Cabinet, Recent Meeting of the Council of the League of Nations, 


\section{Data for Peace: The League of Nations and Disarmament}

January 3, 1924, The National Archives, The Cabinet Papers 1915-1988.

(http://www.nationalarchives.gov.uk/cabinetpapers/)

${ }^{24}$ Katherina Rietzler, "Experts for Peace - Structures and Motivations of the Philanthropic Internationalism in the Interwar Years," in Internationalism Reconfigured: Transnational Ideas and Movements Between the World Wars (London: I.B. Tauris, 2011), 50-51. See also Steiner, The Lights That Failed, 612; Broader emphasis on importance of expertise in economic and financial affairs emphasized in Patricia Clavin, Security the World Economy: The Reinvention of the League of Nations 1920-1946 (Oxford: Oxford University Press, 2013), 21-22, 42-45.

${ }^{25}$ Committee members in early 1924 are listed in The Monthly Summary of the League of Nations - Organizations and Commissions of the League of Nations. Vol. IV, no. 1 (February 15, 1924), 18.

26 “Report of the Temporary Mixed Commission on Armaments," September 15, 1921, 5-6. See also "The Reduction of Armaments, Report of the Temporary Mixed Commission on Armaments," September 7, 1922 in LNP-IX-D (Geneva: League of Nations, 1922), 4-7. (A.31.1922)

27 “Report of the Temporary Mixed Commission on Armaments," September 15, 1921, 2.

28“The Reduction of Armaments, Report of the Temporary Mixed Commission on Armaments," September 7, 1922 in LNP-IX-D (Geneva: League of Nations, 1922), 10-18, 73. (A.31.1922).

29 "Report of the Temporary Mixed Commission on Armaments," September 15, 1921, 5-6. See also "Reduction of Armaments. Report of the Third Committee to the Fourth Assembly, September 27, 1923," LNP-IX-D (Geneva: League of Nations, 1923 1-5), 2. (A111.1923.IX Second Part)

30 “Report of the Temporary Mixed Commission on Armaments," September 15, 1921, 6-7.

31 Andrew Webster, "Making Disarmament Work," 558-559.

${ }^{32}$ Statistical Enquiry into National Peace-Time Armaments, Part I, August 30, 1923, LNP-IX-D (Geneva: League of Nations, 1923); Statistical Enquiry into National Peace-Time Armaments, Part II: Budget Expenditure on National Defence 1921-1923, September 1923, LNP-IX-D (Geneva: League of Nations, 1923). (A.20.1923.IX); "Budget Expenditures on National Defence 1913 and 1920-1922," in LNP-IX-D (Geneva: League of Nations, 1922$), 1-51$. (A.31(a).1922.IX). See also League of Nations, Temporary Mixed Committee for the Reduction of Armaments, Statistical Enquiry into Armaments, (Geneva: League of Nations, 1922). (A.21 1922 IX) 


\section{Data for Peace: The League of Nations and Disarmament 1920-1940}

33 "Reduction of Armaments, I. Work of the Temporary Mixed Commission for the Reduction of Armaments," LNOJ 4(July, 1923), 720. Nokhim Sloutzki, The League of Nations and the Control of Trade in Arms (Cambridge: Center for International Studies, Massachusetts Institute of Technology, June 1974), 97-98.

${ }^{34}$ LNOJ 4(August, 1923), 1031-1036; Quote from Sloutzki, The League of Nations and the Control of Trade in Arms, 98.

${ }^{35}$ Reduction of Armaments. Report of the Third Committee to the Fourth Assembly." September 27, $1923,3$.

${ }^{36}$ Report of the Temporary Mixed Commission for the Reduction of Armaments, Part II, August 15, 1923, LNP-IX-

$D$ (Geneva: League of Nations, 1923), 8. (A.35.(Part II)1923.IX); See also LNOJ 4(August, 1923), $1033-1034$.

${ }^{37}$ The name may also appear as Nahim Sloutzki or Naoum Sloutzki. The last name may also be found as Sloutzky. Nokhim Sloutzki is the spelling used by the League. References to his publications use the spelling in the publication.

38 Completed school form provided by the University of Geneva Archive, entitled "Feuille de Contrôle." Also see Who's Who in the United Nations (Yonkers-on-Hudson, N.Y., C.E. Burckel, [1951]), 403; and LONSEA.org , University of Heidelberg, http://www.lonsea.de/pub/person/5162 (accessed January 31, 2017). Regarding his Nansen passport see Andrew Webster, "The Transnational Dream: Politicians, Diplomats and Soldiers in the League of Nations' Pursuit of International Disarmament, 1920-1938,” Contemporary European History 14, 4(2005), 500.

${ }^{39}$ League of Nations. Economic Committee. Gini, Corrado. Vinci, Felice. Sloutzki, Nokhim M. Report On Certain Aspects Of The Raw Materials Problem (with The Relevant Documents Submitted To The Committee By Professor Gini). 2 Vols. (Geneva: n.p., 1921).

${ }^{40}$ Sloutzki, The League of Nations and the Control of Trade in Arms, $\mathrm{i}$.

${ }^{41}$ N. Sloutzki, "New Destructive Agencies of War," Current History 20, 3(June 1, 1924), 434-439; N. M. Sloutzki, “The World Armaments Race 1919-1939,” Geneva Studies 12, 1(July 1941), 3-129.

${ }^{42}$ For example "The Economist (London), (December 20, 1924), 1041. The cost was 17 shillings, 6 pence or about $\$ 3.87$ in 1924 US dollars.

${ }^{43}$ Löbell's Jahresberichte über die Veränderungen und Fortschritte im Militärwesen (Berlin: Mittler, 1874-1905). From 1906-1913, 1926-1928 see V. Löbell's Jahresberichte über das Heer- und Kriegswesen; and 1929-1935 see Rüstung und Abrüstung: eine Umschau über d. Heer- u. Kriegswesen aller Länder. Similar resource: Alois Veltzé 


\section{Data for Peace: The League of Nations and Disarmament}

and Hugo Kerchnawe, Veltzé Armee-Almanach: ein Militär-Statistisches Handbuch aller Heere (Vienna: C.W. Stern, 1906-1914).

${ }^{44}$ Review of V. Löbell's Jahresberichte über das Heer- und Kriegswesen, Royal United Services Institute for Defence Studies 71(February 1, 1926), 655-657. Examples of other reviews after World War I see Foreign Affairs 8, 1 (October 1929), 156 and Foreign Affairs 10, 1 (October 1931), 156.

${ }^{45}$ Armaments Year-Book (Geneva: League of Nations, 1940), 4. (C.228. M.155. 1939. IX) Armaments Year-Book was published annually as volume 1 of the LNP-IX-D.

${ }^{46}$ Armaments Year-Book (Geneva: League of Nations, 1924), 11, 764-782, 571.

${ }^{47}$ Ibid., 270.

${ }^{48}$ Ibid., 811. Regarding American cooperation see "Washington Gives Arms Figures to League, Aiding Preparation for Disarmament Parley,” New York Times (November 14, 1925), 2; Raymond D. Fosdick, “Cooperating With League: Our Government Congratulated on Change in Procedure," New York Times (November 21, 1925), 16.

${ }^{49}$ Armaments Year-Book (Geneva: League of Nations, 1926), 8-9. (C.373 M.121. 1925.IX).

${ }^{50}$ Mr. Roberts (Geneva) to Sir A. Chamberlain, August 13, 1926. Documents on British Foreign Policy 1919-1939, Series 1A - Volume 2 (London: H.M.S.O, 1968), item 148, p. 256.

${ }^{51}$ Memorandum by Rear-Admiral Bellairs, April 29, 1933 in Documents on British Foreign Policy 1919-1939, Series 2 - Volume 5 (London: H.M.S.O, 1956), item 102, p. 176-179; Telegram from Mr. Patteson (Geneva) to Sir J. Simon, 31st May 1933, Documents on British Foreign Policy 1919-1939, Series 2 - Volume 5 (London: H.M.S.O, 1956), item 190, p. 301-303.

${ }^{52}$ Sir E. Phipps to German Chancellor, December 20, 1933, Documents on British Foreign Policy 1919-1939, Series 2 - Volume 6 (London: H.M.S.O, 1957), item 140, p. 208-210; Record of a Conversation at the Quai d'Orsay at 11.30 [a.m.] on December 22, 1933, Documents on British Foreign Policy 1919-1939, Series 2 - Volume 6 (London: H.M.S.O, 1957), item 144, p. 216-225; Sir E. Phipps (Berlin) to Sir J. Simon, 19th January 1934, Documents on British Foreign Policy 1919-1939, Series 2 - Volume 6 (London: H.M.S.O, 1957), item 191, p. 286-288.

${ }^{53}$ CAB/24/247/64, Cabinet, Imperial Defence Policy, Report of the Defence Requirements Committee dated February 28, 1934 (D.R.C. 14), submitted to the cabinet March 5, 1934; CAB/24/254/35. Air Ministry Letter to Foreign Office, April 5, 1935, respecting certain of Herr Hitler's Statements at Berlin Conversations regarding Air 


\section{Data for Peace: The League of Nations and Disarmament 1920-1940}

Armaments, Annex 4 of secret Cabinet Memorandum on Questions for Discussion at Stresa Conference. The National Archives, The Cabinet Papers 1915-1988. ( http://www.nationalarchives.gov.uk/cabinetpapers/ )

${ }^{54}$ Hansard Debates 1803-2005. http://hansard.millbanksystems.com/search/\%22armaments+year+book\%22?=C20 (accessed January 31, 2017) cites the Year-Book 27 times, and Parliamentary Papers (Proquest) database cites the yearbook in 3 sessional papers. For the reference to Sassoon, see Hansard, $5^{\text {th }}$ Series, v. 317 (November 11, 1936), 858. For Chamberlain's comments see Hansard, $5^{\text {th }}$ Series, v. 346 (May 1, 1939), 1500.

55 A Full text search of Proquest Congressional for 1924-1940 cites the yearbook 9 times in the Congressional Record and Congressional documents not including bibliographies. Reference to Ross Collins in Congressional Record (June 8, 1932), $72^{\text {nd }}$ Congress, $1^{\text {st }}$ Session, p. 12358-12359. See also Rep. Abram P. Andrew, Jr. on relations between France and the US in Congressional Record (June 2, 1926), 69 ${ }^{\text {st }}$ Congress, $1^{\text {st }}$ Session, 10523.

56 Sample of reviews: “The World in Arms" New Statesman (January 24, 1925), 454; Pierre Dame, [Review of Annuaire Militaire, 1929], Revue des Sciences Politiques 53 (1930), 149-150; H. R. Raikes, “Armaments Year-Book of the League of Nations," The South African Journal of Economics 5 (January 1, 1937), 333; Sigfrid Mette [Review of 1929/20, 1930/31], Zeitschrift für Politik, 21 (1932), 952-954; Adolf Grabowsky, [Review of special 1932 edition], Zeitschrift für Politik, 21 (1932), 954; Russell E. Hall, [Review of Armaments Year-Book 1936], Pacific Affairs, 11, 1 (March, 1938), 140; Hans Wehberg, [Review of Annuaire Militaire 1939/40], Die Friedens-Warte: Blätter für internationale Verständigung und zwischenstaatliche Organisation 40, $3 / 4$ (1940), 251. There are frequent references and reviews to Annuaire Militaire in Die Friedens-Warte.

57 “Hughes Evasive Fosdick Charges: Dissecting Secretary's Reply on League,” New York Times (Oct 27, 1924$), 22$. Fosdick was Wilson's under-secretary general of the League until the Senate rejected the League.

${ }^{58}$ Sample of yearbook used as a source: “Annuaire Militaire 1924,” Hamburger Nachrichten (January 30, 1925), 1; Frederick Maurice, “Disarmament, Paper Read on May 4, 1926,” Journal of the Royal Institute of International Affairs 5, 3 (May, 1926), 124, 133; Edward S. Williams, Lt. Commander, R.N. (retired), "Size of British Forces," The Times [London] (November 17, 1927), 15; La Guerre hors la Loi,' L'Humanité (November 15, 1927), 1; Charles A. Beard, "Bigger and Better Armaments," Harper's Magazine_(January 1, 1929); 133; "Le Désarmement et les Budgets Militaires: Les Dépenses de Défense Nationale des Différentes Puissances,” Le Temps (June 26, 1932), 1; "The World Over," The Living Age (January, 1933), 382; Walter Consuelo Langsam, “Maladjustments of the Peace Settlement," Annals of the American Academy of Political and Social Science, 175 (September, 1934), 4; 


\section{Data for Peace: The League of Nations and Disarmament}

"Wide Rise in Arms Shown By League," New York Times (June 25, 1935), 11; "Les Armements Mondiaux et Européens," Journal des Débats 315(November 13, 1936), 3; Also see French and German newspapers from The European Library database (http://www.theeuropeanlibrary.org/tel4/newspapers); Google Scholar, Google Books, and Periodicals Archive Online.

${ }^{59}$ P. J. Noel Baker, “Armaments,” Nation and Athenaeum (June 19, 1926), 324.

${ }^{60}$ P. W. Wilson, “The Cost of Arms in \$3,500,000,000 at Year,” New York Times (August 12, 1928 ), 21.

61 “Army Reforms and Air Defence,” The Times [London] (December 21, 1937), 19.

${ }^{62}$ Andrew Webster, "Making Disarmament Work," 563.

${ }^{63}$ G. Lestien, [Review of Annuaire Militaire de la Société des Nations], La Quinzaine Critique des Livres et des Revues 2, 20(October 25, 1930), 562-563. See also German comments and references in Heinrich Schnee, Zehn Jahre Versailles, II Band, Die Politischen Folgen des Versailler Vertrages (Berlin Brückenverlag, 1929), 117-118, 128.

${ }^{64}$ Myers, World Disarmament: Its Problems and Prospects, 124-127, 197 (quote)-198; See also John W. WheelerBennett, Disarmament and Security Since Locarno 1925-1931 (New York: Howard Fertig, 1973$), 95$.

${ }^{65}$ William T. Stone, [Review of Armaments Year-Book], Pacific Affairs, Vol. 8, No. 1 (Mar., 1935), 124-125. See also a brief critique comparing with Rüstung und Abrüstung (see note 52) from Hans Rohde, "A Critical Guide to International Literature on Disarmament since 1931," in Disarmament and Equal Rights: Facts and Problems Dealt With in the Negotiations on Disarmament and Equal Right 1933/1934 (Berlin: Carl Heymanns Verlag, 1934), 146, 163.

${ }^{66}$ League of Nations, Preparatory Commission for the Disarmament Conference, "Report to the Council on the Work of the First Session of the Commission held at Geneva from May 18th to 26th, 1926," LNP-IX-D (Geneva: League of Nations, 1926), 2. (C. 301. 1926. IX); See also the 1930 Draft Convention that included categories of measurements, tables for illustrating data, and specific numerical limitations in armaments in League of Nations, Preparatory Commission for the Disarmament Conference, "Draft Convention," LNP-IX-D (Geneva: League of Nations, 1930). (C687.288.1930 IX ) 


\section{Data for Peace: The League of Nations and Disarmament 1920-1940}

${ }^{67}$ Arthur Henderson, “Opening Speech by the President," in League of Nations, Conference for the Reduction and Limitation of Armaments, Verbatim Record (Revised) or the First Plenary Meeting, February 2, 1932 (Geneva: League of Nations, 1932), 44-45. (Conf D./P. -V.1. (1))

${ }^{68}$ Armaments Year-Book, Special Edition (Geneva: League of Nations, 1932), 3. LNP-IX-D1932. IX. 1.

(C754.M.352.1931.IX. Conf. D. 40); LNOJ 2(October 1932), 1636-1637.

${ }^{69}$ Armaments Year-Book, Special Edition, 1932, 4.

${ }^{70}$ National surveys appear under the general heading "Particulars with Regard to the Position of Armaments in the Various Countries" in LNP-IX-D(Geneva: League of Nations, 1931), documents 7-42 and LNP-IX-D (Geneva: League of Nations, 1932), documents 2-4, 8-16, 20, 29.

${ }^{71}$ Myers, World Disarmament: Its Problems Prospects, 126-127, 356-364. In Appendix III Myers juxtaposes data from the "Particulars" document with data from Armaments Year-Book to illustrate differences in result.

${ }^{72}$ LNOJ 3(May 1922), 405 and 5(October 1924), 1363; Statistical Information on the Trade in Arms and Ammunition, and Material of War (Geneva: League of Nations, 1924), 4-6; (A.30.1924.IX);

${ }^{73}$ Statistical Information on the Trade in Arms and Ammunition, and Materials of War (Geneva: League of Nations, 1927), 40-41. (C.438.M.168.1926.IX); Statistical Year-Book of the Trade in Arms and Ammunition (Geneva: League of Nations), 253. (C.263.M.156.1938.IX)

${ }^{74}$ Sloutzki, The League of Nations and the Control of Trade in Arms, 91-96, 109 (quote), 110-122

75 John Gunther, “Slaughter For Sale,” Harper's Monthly Magazine (May 1, 1034), 650. See also Clarence K.

Streit, “The World's Munition Trade: Its Extent and the Profits,” New York Times (November 20, 1932 ), 3.

${ }^{76}$ Sir J. Simon to Sir A. Cadogan (Peking), May 9, 1934 in Documents on British Foreign Policy 1919-1939, Series 2 - Volume 20 (London: H.M.S.O, 1984), item 132, p. 241-243; Hansard, 1933-1934, $5^{\text {th }}$ series, v. 283 (December 4, 1933), 1307-1308; Hansard 1934-1935, $5^{\text {th }}$ series, v. 295 (November 22, 1934), 280-283.

${ }^{77}$ Sloutzki, The League of Nations and the Control of Trade in Arms, 110-113.

78 Sloutski, “The World Armaments Race 1919-1939,” 9.

${ }^{79}$ Keith Hamilton and Edward Johnson, Arms and Disarmament in Diplomacy, 2-3. See also Jozef Goldblat, Arms Control: The New Guide to Negotiations and Agreements, $2^{\text {nd }}$ Ed., 19-20.

${ }^{80}$ B. J. C. McKercher, “Of Horns and Teeth: The Preparatory Commission and the World Disarmament Conference, 1926-1936," in Arms Limitation and Disarmament: Restraints on War, 1899-1939, 182. 


\section{Data for Peace: The League of Nations and Disarmament}

${ }^{81}$ Steiner, The Triumph of the Dark, 55-56; Steiner, The Lights That Failed, 796, 812-813

${ }^{82}$ Sloutzki, The League of Nations and the Control of Trade in Arms, 109.

${ }^{83}$ Stone, [Review of Armaments Year-Book], Pacific Affairs, Vol. 8, No. 1 (March 1935), 124.

${ }^{84}$ Armaments Year-Book, Special Edition, 1932, 184. LNP-IX-D1932. IX. 1. (C754.M.352.1931.IX. Conf. D.40);

Armaments Year-Book 1939/40 (Geneva: League of Nations, 1940), 228. LNP-IX-D1940 (C.228.M.155.1939.IX.

IX. 1)

${ }^{85}$ Sloutzki, The League of Nations and the Control of Trade in Arms, 110.

${ }^{86}$ Walters, A History of the League of Nations, v. 2, 553-554.

${ }^{87}$ Patricia Clavin, Securing the World Economy, 342-351, (quote) 347; See also Alan James, “The United Nations' Debt to the League of Nations," 86-93 in The League of Nations 1920-1946, New York: United Nations, 1996; Martyn Housden, The League of Nations and the Organization of Peace, (Harlow: Longman), 2012, 111-113; J. Simon Rofe, "Prewar and Wartime Postwar Planning: Antecedents to the UN Moment in San Francisco, 1945," 2031; Ruth Henig, "A League of its Own,” History Today (February 2010), 3-4; M. Patrick Cottrell, The Evolution and Legitimacy of International Security Institutions, 65-99.

${ }^{88}$ Charter of the United Nations and Statute of the International Court of Justice (San Francisco, 1945), 4, 7, 10.

89 "Principles Governing the General Regulation and Reduction Of Armaments," Resolution, UN General Assembly, $1^{\text {st }}$ Session, 63 ${ }^{\text {rd }}$ Plenary Session (December 14, 1946), 65-67. A/RES/41(I); "Information On Armed Forces To Be Supplied By Members of The United Nations," Resolution, UN General Assembly $1^{\text {st }}$ Session, $63^{\text {rd }}$ Plenary Session (December 14, 1946), 67. A/RES/42(I); "General and Complete Disarmament," Resolution, UN General Assembly, 30th session, 2439 ${ }^{\text {th }}$ Plenary Session (December 12, 1975), 31-32. A/RES/3484(XXX)B 90 "United States of America: Working Paper Setting Forth Proposals For Progressive and Continuing Disclosure and Verification of Armed Forces And Armaments, April 5, 1952," in Disarmament and Security: A Collection of Documents (Washington, D.C.: US Government Printing Office, 1956), 318-325. 


\section{Data for Peace: The League of Nations and Disarmament 1920-1940}

${ }^{91}$ Military Balance (International Institute of Strategic Studies, 1961-); World Military and Social Expenditures (Leesburg, Va.: World Priorities, 1974-1996 and related titles World Defense Expenditures (1966), World Military Expenditures (1967-1973), World Military Expenditures and Arms Trade (1969-1971), and World Military Expenditures and Arms Transfers (1967-2000) at Washington, D.C.: US Arms Control and Disarmament Agency; SIPRI Yearbook of World Armaments and Disarmament (Humanities Press, 1968-).

${ }^{92}$ Yearbook of the United Nations 1980 (New York: United Nations, 1983), 78-81; The UN Report on Military Expenditures (United Nations, 2000- present but title varies with reporting history) is online at http://www.unarm.org/Milex/home.aspx .

93 “Conventional Disarmament: The UN Expert Panels on Small Arms \& UN Arms Register,” 131-132 in Disarmament: The Future of Disarmament. Edited Transcripts of the forums held in the United Nations... New York: United Nations, 1998. Edward J. Laurance et. al., Arms Watch: SIPRI Report on the First Year of the UN Register of Conventional Arms (Oxford: Oxford University Press, 1993), 6-9. Access to the UN Register of Conventional Arms at https://www.unroca.org/ ; Access to The Global Reported Arms Trade at http://www.unregister.org/HeavyWeapons/Index.aspx (accessed January 31, 2017).

${ }^{94}$ For example data sources relying in part on Armaments Year-Book are J. David Singer, Wages of War, 18161965: A Statistics Handbook (Wiley, 1972); Correlates of War.org initiated by Singer and Mel Small and their National Materials Capabilities Data (ICPSR 1993 file 37); Resort to War: A Data Guide to Inter-State, Extra-State, Intra-State, and Non-State Wars 1816-2007 (Washington, DC: Congressional Quarterly Press), 2010. 